\title{
Aung San Suu Kyi's Defensive Denial of the Rohingya Massacre: A Rhetorical Analysis of Denial and Positive-Image Construction
}

\author{
Idhamsyah Eka Putra ${ }^{1,2}$, Hema Preya Selvanathan ${ }^{3}$, Ali Mashuri ${ }^{4}$, Cristina J. Montiel ${ }^{5}$ \\ [1] Faculty of Psychology, Persada Indonesia University, Jakarta, Indonesia. [2] Division for Applied Social Psychology Research (DASPR), fakarta, Indonesia. \\ [3] School of Psychology, The University of Queensland, Brisbane, Australia. [4] Faculty of Social and Political Sciences, University of Brawijaya, Malang, \\ Indonesia. [5] Department of Psychology, Ateneo de Manila University, Quezon City, Philippines.
}

Journal of Social and Political Psychology, 2021, Vol. 9(2), 353-369, https://doi.org/10.5964/jspp.7301

Received: 2020-04-09 • Accepted: 2021-06-16 • Published (VoR): 2021-08-26

Handling Editor: Johanna Vollhardt, Clark University, Worcester, MA, USA

Corresponding Author: Idhamsyah Eka Putra, Universitas Persada Indonesia, Jl. Diponegoro No. 74 Jakarta Pusat, Indonesia. E-mail: idhamsyah.eka@upiyai.ac.id

Supplementary Materials: Materials [see Index of Supplementary Materials]

\begin{abstract}
In December 2019, the International Court of Justice (ICJ) accused the Myanmar government of genocide against Rohingya Muslims. Represented by Nobel Peace Prize winner Aung San Suu Kyi, Myanmar authorities denied such accusations. To understand how a political leader can deny ingroup wrongdoings, we unpacked Suu Kyi's ICJ speech and analyzed her defensive rhetorical style through critical narrative analysis. We aimed to identify and describe the denial strategies Suu Kyi used as well as how she maintained a positive ingroup image to support her position. Our findings showed that Suu Kyi engaged in interpretative denial of genocide by arguing that genocide cannot occur when there is armed conflict, that there were victims and perpetrators on both sides, and that misconducts by law enforcement had been addressed. To maintain the ingroup's positive image, she portrayed Myanmar as moral by emphasizing the government's knowledge of ethical standards and laws, as well as their support for peace and justice. By examining political discourse used by a national leader internationally renowned for supporting human rights, our findings shed light on the dynamic, constructive nature of denial. Theoretical and applied contributions to understanding denial of ingroup wrongdoing are discussed.
\end{abstract}

\section{Keywords}

denial, ingroup wrongdoing, genocide, mass violence, competitive victimhood, ingroup image, moral disengagement

\section{Non-Technical Summary}

\section{Background}

The Rohingya Muslims are a highly persecuted ethnic minority in Myanmar. In November 2019, The Gambia lodged a case in the International Court of Justice (ICJ) accusing Myanmar of committing genocide against the Rohingya people. In December 2019, Aung San Suu Kyi, an international icon of democracy from Myanmar, represented her country at the ICJ and denied accusations of genocide.

\section{Why was this study done?}

Our goal was to understand the arguments that Suu Kyi constructed to defend Myanmar against accusations of genocide. Specifically, we focused on the denial strategies she used and the way she maintained a positive image of Myanmar to persuade 
the audience at the ICJ to adopt her political position. By focusing on her linguistic style, we aimed to contribute to the understanding of how perpetrators of mass violence psychologically defend themselves to avoid facing moral sanctions.

\section{What did the researchers do and find?}

We analysed Suu Kyi's speech at the ICJ as the main data, and also examined her media interviews on the topic as complimentary data. We focused on how and why the arguments are made, while also considering Suu Kyi's role as a peace activist. Our approach also critically considered the perspectives that were highlighted and those that were downplayed or omitted to advance a particular argument. Our findings showed that Suu Kyi engaged in interpretive denial, a strategy where perpetrators admit that some degree of wrongdoing was committed but they deny the implications of those actions. Her arguments highlighted the idea that 1) the killings are not genocidal because there was armed conflict, 2) that the Rohingya were not the only victims of the conflict, 3) the Rohingya were also perpetrators, and 3) misconducts by law enforcement had been addressed. She likewise constructed a positive image of the Myanmar government by emphasizing that 1) they knew the rule of law and the consequences for violating it, and 2) they were supporters of peace and justice.

\section{What do these findings mean?}

Our research shows how defensive strategies to deny ingroup atrocities are used by a leader renowned for peace activism. This was done by using denial strategies that are in part supported by constructing a positive group image. This suggests that to intervene and/or punish offenders of mass atrocities, there is a need to critically consider whether and how past moral behaviors and group reputation should factor into these decisions. How the narrative is framed and told also can be used as a persuasive approach of denial arguments and to boost positive image construction.

"When one-third of the Rohingya population had to flee the country, could you find a better word to describe it?" Antonio Guterres, UN Secretary General

At the International Court of Justice (hereafter ICJ) in December 2019, The Gambia and 57 other members of the Organization of Islamic Cooperation (OIC) accused the Myanmar government of committing genocide in its treatment against Rohingya Muslims (Aljazeera, 2019). Myanmar denied the accusation. Although perpetrators of mass killings usually deny their criminal acts (Leach, Zeineddine, \& Čehajić-Clancy, 2013), Myanmar's case stands out because the alleged genocide was defended by Nobel Peace Prize Laureate Aung San Suu Kyi. It is often the case that mass atrocities such as genocide are heavily contested, which affects the victim group's (Vollhardt, Mazur, \& Lemahieu, 2014) and bystander's (Leidner, 2015) support for intergroup reconciliation in the aftermath of genocide.

Our study analyzes Suu Kyi's rhetorical defense of her country's contended genocide. In general, we are interested in understanding the ways in which Suu Kyi addressed the accusation of genocide, the denial strategies she used, and how she attempted to maintain a positive image of Myanmar. In addition, we examine whether her responses can be connected to her identity as a peace activist and how this is similar or different to other accused cases of genocide. We first review the literature on rhetoric as politically performative, and why groups engage in denial of past wrongdoings. We then describe the societal context of Rohingya Muslims in Myanmar.

\section{Rhetoric as Politically Performative}

We situate our analytical lens at the crossroads of discourse, psychology, and politics, wherein spoken words or text written by those in power aim to achieve their political goals (Souto-Manning, 2014). Political discourse is therefore performative in the sense that rhetoric can be a social act (i.e., to do something in a social environment) driven by particular goals, including justifications, denials, excuses, reproach, accusations, and rebuttals (Edwards, 1991; Le Couteur \& Augoustinos, 2001; Montiel, Umel, \& de Leon, 2016). We posit that one overriding goal among politicians and political leaders, especially in contested public spheres, is to win support from third party groups - who may not have 
a direct stake in the conflict but are nonetheless important to advance a political aim (see Simon \& Klandermans, 2001). This is why it is important to look at how political leaders deny ingroup wrongdoings in their public speeches.

Accordingly, we conceptualize Aung Suu Kyi's speech at the ICJ as political rhetoric performed to win over the ICJ decision-makers. We argue that Aung Suu Kyi's rhetoric aimed to influence the ICJ in favor of Myanmar, because the ICJ were the judges in a court contestation lodged by the Organization of Islamic Cooperation against the Myanmar government over the treatment of Rohingya Muslims in the country. To understand her rhetoric, we turn to how groups may strategically deny their ingroup's wrongdoing.

\section{Denial of Ingroup Wrongdoing and its Rhetorical Arguments}

One's ingroup is a powerful source of moral guidance on how to live our lives and interact with others. Accordingly, when faced with accusations of group-based wrongdoings such as mass killings or genocide, ingroup members may defend their ingroup (e.g., Bilali, 2013; Brown, Zagefka, González, Manzi, \& Čehajić, 2008; Peetz, Gunn, \& Wilson, 2010; Putra, Wagner, Rufaedah, \& Holtz, 2019). Denying the crimes committed by one's ingroup helps prevent the group from facing the punitive consequences and moral sanctions of their transgression. This is one of the strategies Bandura (1999) describes as moral disengagement (see also Leidner, Castano, Zaiser, \& Giner-Sorolla, 2010).

To understand the ways in which ingroup members deny or fail to admit ingroup wrongdoing, previous findings can be conceptualized under the three types of denial strategies first outlined by Cohen (2001). The first denial strategy is literal denial, which is when the accused group claims that the wrongdoing against outgroup members never happened. For example, Holocaust deniers claim that the Nazi genocide of European Jews during World War II was a hoax despite extensive evidence to the contrary (Shermer \& Grobman, 2009). Literal denials are further exacerbated by rhetorical counter accusations that call the victim's claim a lie, slander, fraud, or hoax.

A second type of denial pertains to interpretative denial (Cohen, 2001). In such cases, accused perpetrators admit ingroup wrongdoings, yet deny the impact or implications of those actions. Muslim massacres in Bosnia and Herzegovina between 1992 and 1995 exemplify this. Serbian leaders acknowledged that the killings indeed targeted Muslims in Bosnia and Herzegovina, yet Serbs labeled such atrocities as tragedies and crimes, avoiding the word 'genocide' (Parent, 2016). Interpretative denial can also emerge when perpetrators position themselves as victims, as in the case of the Austrian government that avoided acknowledging the Holocaust by pointing out that Austrians were considered victims of the Nazis as well (Wodak, 2006). This is related to the phenomenon of competitive victimhood (Noor, Shnabel, Halabi, \& Nadler, 2012), whereby perpetrator groups attempt to establish that their ingroup suffered the most, which can trigger an escalating spiral of counter accusations between groups.

Building on Cohen (2001)'s theorizing on interpretative denial, we consider the diffusion (or shifting) of responsibility as another rhetorical strategy for interpretative denial (see Wodak, 1991). As Bandura (1999) describes, the accused may use moral disengagement strategies to deny their own responsibility by claiming the incident was someone else's fault or was an order from someone more superior (e.g., a national leader). By finding ways to justify unethical and inhumane conducts, they free themselves and their group from moral condemnation. A good illustration of this is the confession of Adolf Eichman during his trial in 1961 when he was charged for the Holocaust and other war crimes. Eichman admitted that he helped organize the Holocaust, but claimed he was just following orders and had no other choice.

In a third type of denial called implicatory denial, accused perpetrators admit the acts, but do not acknowledge such acts as wrong (Cohen, 2001). This form of denial was evident in Indonesia during the years 1965 to 1966, when communists were socially constructed as evil and a threat to unity in the country. This line of thinking legitimized the eradication of an estimated 500,000 to 1 million Indonesians accused as communists responsible for widespread violence and hence deserving of their punishment (Putra et al., 2019).

Drawing on these distinctions, in the present research we examine the dynamic of Suu Kyi's rhetorical denial of the Rohingya massacre, specifically for whether there is evidence of literal, interpretative, and/or implicatory denial. 


\section{Constructing a Positive Ingroup Image}

In thinking about a leader's denial strategies of ingroup wrongdoing, it is also important to consider the psychological function that this strategy serves for the perpetrator group. Since people are motivated to perceive their ingroup in a positive light, acknowledgements of ingroup wrongdoings could bring shame to the group, undermine ingroup dignity or pride, and promote defensiveness (e.g., Brown et al., 2008; Peetz et al., 2010; Wohl, Branscombe, \& Klar, 2006).

Along with the denial of wrongdoing, accused perpetrators may present themselves as tolerant, trustful, and kind to maintain a positive image of their group. It is possible that both denial and positive image arguments are two manifestations of the same motivation, and analyzing them in tandem can help us understand the interpretative power of the speaker's expressions. While denial arguments are a defensive strategy (e.g., "it was a hoax" or "it was an accident"), the construction of the ingroup's positive image is meant to persuade others of the denial arguments. Thus, one way to understand the link between denial arguments and construction of a positive group image is that the former provides a logical basis for the latter.

From the social identity perspective on leadership, we know that leaders are often viewed as prototypical group members, such that the leader's position and arguments most clearly differentiate the ingroup from relevant outgroups (Haslam, Reicher, \& Platow, 2011). To be effective, it is important for a leader to be seen as having the group's best interest at heart and viewed by ingroup members as "doing it for us" (Reicher, Haslam, \& Hopkins, 2005). Leaders also play a key role in shaping the outcomes of group-based conflicts: It is through the actions of leaders that an intergroup conflict might end in reconciliation (Morselli \& Passini, 2010) or mass killings (Wodak, de Cillia, Reisigl, \& Liebhart, 2009).

One of the strategies group members use to maintain a positive group image is to convince others that good people cannot engage in bad behaviors (Augoustinos \& Every, 2007). Cases like this are often found when people engage in prejudice denial, by claiming "we are not racist" or "our people are generous". Such positive claims are typically followed by conjunction words like "but" or "however", to bridge an explanation of ingroup values that are under threat (Augoustinos \& Every, 2007; see also Chiang, 2010). Such rhetoric highlights the morality of the ingroup while at the same time justifying discriminatory policies against outgroups to ensure the best interest of the ingroup is protected.

In the context of mass violence, an example of positive image construction occurred during the Cambodian Genocide of the 1970s under Pol Pot's government to turn the country into a socialist and communist state. The genocide took the lives of around a fourth of the country's population (Kiernan, 2003). Pol Pot, however, denied the genocide and described himself as far from savage. Instead, he claimed that it is impossible for him to kill his own people as his struggle was for the sake of the Cambodian people (Maguire, 2005). Taken together, positive image construction by a national leader is an important method that is central to the denial of wrongdoings. Next, to contextualize our research questions on denial and positive image-construction, we present a brief overview of the context in Myanmar.

\section{Societal Context: Rohingya Muslims and Aung San Suu Kyi}

\section{Who Are the Rohingya?}

In general, the Rohingya people refers to a Muslim ethnoreligious group from the northern Rakhine state of Western Myanmar known as the Arakan state (Parnini, 2013). Rohingya are descendants of Arab, Moorish, Persians, Moghul, Turks, Pathan, or Bengalis (Rahman, 2010). In contrast with the majority Buddhist Burmese and Rakhine who speak Burmese or Rakhine, the Rohingya speak Bengali. Since February 1978, the Rohingya people were persecuted and over two hundred thousand of them were forced to seek refuge, particularly in Bangladesh (Parnini, 2013). In 1982, a citizenship law stripped the Rohingya of Myanmar citizenship, making them de jure stateless people (Haque, 2017). At the time of writing, Rohingya continue to suffer human rights' violations under the Myanmar government and many of those living in refugee camps face protracted displacement (Xchange.org, 2019).

\section{Aung San Suu Kyi and the Present Study}

Aung San Suu Kyi ${ }^{1}$ is the daughter of independence hero General Aung San and Daw Khin Kyi. In September 1988, Suu Kyi co-founded the National League for Democracy (NLD). Considered a threat by the then Myanmar leader of 
the newly formed military junta ${ }^{2}$, Suu Kyi was placed under house arrest from 1989 to 2010. It was during this time that Suu Kyi received the 1991 Nobel Peace Prize for her non-violent struggle for democracy. Upon her release in 2010, Suu Kyi led the oppositionist political movement. Given her role in Myanmar's democratic transition, Suu Kyi became internationally renowned for her activism. Since 2016, Suu Kyi has held key government positions such as Foreign Minister and State Counselor of Myanmar.

However, political developments unravel rapidly in new democracies. The Myanmar military again effected a successful power grab on 1 February 2021 (BBC, 2021). General Min Aung Hlaing, accused as the mastermind of the Rohingya genocide in 2017 (UNHRC, 2018), led the coup in early February 2021. As of this writing, military general Myint Swe serves as acting President; national leader Aung San Suu Kyi is in prison again.

Since the Rohingya crisis gained worldwide prominence in August 2017, Suu Kyi had been widely criticised for her silence (Lee, 2014) on the state's violent treatment of the Rohingya and for failing to condemn the violence. In December 2019, in her official government capacities, Suu Kyi delivered a speech to the ICJ to legally defend the Myanmar government and military against genocidal accusations of the Rohingya Muslims. As far as we know, Suu Kyi was not involved first-hand in the killings, and neither was she accused of ordering the killings. In January 2020, the judges at the ICJ ordered Myanmar to take emergency measures to protect the Rohingya from genocide.

Specifically, within the context of the Rohingya genocide in Myanmar, we first investigated the denial strategies that Suu Kyi, as a leader of Myanmar and a prominent peace activist, engaged in to defend her country against the accusation of mass killings. Second, we explored the strategies that Suu Kyi used to defend and protect the ingroup's positive image. By analysing her rhetorical strategies, our approach adds to psychological literature on denial of collective violence, which has largely taken a quantitative approach to examine the predictors and outcomes of denial of ingroup wrongdoings (e.g., Bilali \& Vollhardt, 2019; Wohl et al., 2006). We contribute to the dearth of qualitative approaches on how denial arguments are constructed and expressed by groups.

\section{Method}

\section{Data}

Our primary data source was Suu Kyi's speech in the ICJ on 12th December 2019, when she defended Myanmar from accusations of mass killings, rape, and expulsion of the mostly Muslim Rohingya minority. The video of Suu Kyi's ICJ speech can be found on YouTube and the transcript in Al Jazeera. ${ }^{3}$ There were also interviews by BBC's Fergal Keane in April 2017 and BBC' Mishal Husain in October 2013. We used these interviews as secondary data to check for the consistency of Suu Kyi’s arguments on the Rohingya case. To differentiate Suu Kyi’s speech at the ICJ, we coded 2013 interview as "Suu Kyi, 2013" and 2017 interview as "Suu Kyi, 2017".

\section{Analytical Approach}

There are many different approaches used to analyze discourses and rhetorical narratives (Gibson, 2013; Parker, 2013). In the present study, we utilized critical narrative analysis (CNA; Souto-Manning, 2014) to understand how the narrative is told, and to analyze the speaker critically as the representative of the country, by considering her position and self-descriptions. This approach further questions the perspective that is presented or highlighted as well as the perspectives that are omitted or underplayed.

1) The references of the first two paragraphs for Suu Kyi' background are wholly based on Popham (2012), Pletcher (2019) and Internet archives: http:// factsanddetails.com/southeast-asia/Myanmar/sub5_5b/entry-3015.html

2) The military was in power from 1962 to 2011 and was still considered a powerful faction in Myanmar during the ICJ inquiry.

3) Suu Kyi's speech in ICJ can be viewed through this link: https://www.youtube.com/watch?v=KI4L0bt0Kno, and the transcript through this link: https:// www.aljazeera.com/news/2019/12/transcript-aung-san-suu-kyi-speech-icj-full-191212085257384.html

4) 2017 interview can be viewed through this link: https://www.youtube.com/watch?v=MFEEmdKbqBE, and 2013 interview through this link: https:// www.youtube.com/watch?v=rNVE_Ch_Q18 
CNA draws on both narrative analysis and critical discourse analysis (for a review, see Souto-Manning, 2014). Narrative analysis (Murray, 2003) focuses on the ways stories are crafted by speaker(s) and how these stories are used to understand phenomena or social events. Critical discourse analysis (Van Dijk, 1993) examines spoken or written text by critically investigating the role of social power and ideology. Thus, it focuses more on the speaker's characteristics (e.g., socioeconomic background, social status) and the social context in which the text is delivered (who is the recipient/audience, mode/method of communication, type of topics). By mixing the approaches of narrative and critical discourse analysis, CNA "allows us to learn how people create their selves in constant social interactions at both personal and institutional levels, and how institutional discourses influence and are influenced by personal everyday narratives" (Souto-Manning, 2014, p. 163). Thus, through CNA, often the nuance of the analysis is (radically) constructive (Madill, Jordan, \& Shirley, 2000) by seeing how the data (i.e., speech) constructs its objects and subjects, how it represents reality, and how it is related to the context. This is particularly important in political speeches or statements in which leaders may incorporate personal or everyday narratives in their institutional discourse.

Particularly, we used CNA as an analytical framework to analyze why and how Suu Kyi denied Gambia's accusation of genocide in her speech at the ICJ. In CNA terms, we assume her speech uses narratives as rhetorical strategies (Souto-Manning, 2014) to convince and persuade the audience to accept a particular political position. Accordingly, we watched and/or read the data thoroughly and critically examined it to understand how Suu Kyi constructed her reasoning, what she highlighted, and what she downplayed or did not clearly communicate. We likewise considered Suu Kyi's background, personal capacity, and social position. We noted how Suu Kyi's speech was prepared as somewhat connected to her as a person (i.e, her background, experience, values) and as part of her ingroup status as Myanmar's representative (i.e, group values, norms, history). Hence, we were also interested in Suu Kyi's perspective and story about Rohingya. Beyond what was spoken or expressed, we also attempted to understand possible hidden meanings of her arguments.

In the first step of analysis, the first author selected statements related to categories on denial and/or positive image construction. The categorized statements were then checked and evaluated by the third and fourth authors. After the themes were considered to capture what is expressed by the data, the first, third, and fourth authors finalized the content of the themes. Any differences in interpretations were resolved through discussion. All authors were of Southeast Asian descent from neighboring countries to Myanmar (i.e., from Indonesia, Malaysia, and the Philippines). We therefore had related cultural knowledge of the situation given the similarities and parallel histories between our home countries and Myanmar. Our approach in defining the themes was inductive and followed a bottom-up process (Howitt, 2010) in which we started by identifying the categories observed in the data that fit our theoretical framework. In the results section below, we present extracts selected as exemplars of key findings, and break down the findings into two main themes: Suu Kyi's denial of genocide and positive image construction.

\section{Results}

\section{Suu Kyi’s Denial of Genocide}

Our findings show how Suu Kyi used interpretative denial of genocide to defend Myanmar at the ICJ. She admitted the existence of widespread killings of the Rohingyas and at the same time, implied that acts of genocide are indeed wrong. Her primary rhetorical defense was in the interpretation of the mass killings as non-genocidal. In her speech, we found four types of rhetorical denial arguments: 1) It is not genocide when there is armed conflict; 2) Both sides are victims; 3) Both sides are perpetrators; 4) Misconducts by law enforcement have been addressed. We describe each in detail below.

\section{"It Is Not Genocide When There Is Armed Conflict Causing Displacement"}

In her speech, Suu Kyi defined genocide, with reference to UN's 1948 Convention on the Prevention and Punishment of the Crime of Genocide in Article II $^{5}$, as acts of whole or partial destructions against a national, ethnic, racial, or religious group. She then argued that what happened in Rakhine was not genocide but armed conflict. According to Suu Kyi, because of this armed conflict, people moved away from their homes to find a safer place. She argued that 
such displacement could not be labeled as 'genocide', citing historical examples of cases classified as genocide and non-genocide:

\section{Extract $1^{6}$}

[T] 1948 Genocide Convention is a matter of utmost gravity [...] and that my country wholeheartedly signed as early as December 30, 1949, and ratified on March 14, 1956. Genocide is the crime that the International Criminal Tribunal for Rwanda applied in response to the mass-killing of [...] Tutsis in Rwanda. It is the crime that was not applied by the Tribunal for the former Yugoslavia to the displacement of approximately one million residents of Kosovo in 1999. Neither was it applied by that Tribunal nor by this Court when deciding upon the exodus of the Serb population from Croatia in 1995. In both situations, international justice resisted the temptation to use this strongest of legal classifications because the requisite specific intent to physically destroy the targeted group in whole or in part was not present.

In the statement, Suu Kyi showed that she was deeply knowledgeable about the UN 1948 Convention and the subsequent cases. Further, she stated that people from Rakhine currently living in shelters or neighboring countries were not the victims of systematic killing, but armed conflict:

\section{Extract 2}

The situation in Rakhine is complex and not easy to fathom. But one thing surely touches all of us equally: the sufferings of the many innocent people whose lives were torn apart as a consequence of the armed conflicts of 2016 and 2017, in particular, those who have had to flee their homes and are now living in camps in Cox's Bazar.

Based on the extract above, Suu Kyi acknowledged that there were problems in Rakhine State, but denied that such problems were part of systematic killing, as accused by The Gambia.

Such framing above was consistent with her later interviews by BBC in 2013 and 2017 that the victims were the consequence of the armed conflict. Hence, she built an argument that the main impact of the conflict was displacement, in that people were forced to become refugees to escape the conflict. Interestingly, in both interviews and in the quote above, Suu Kyi did not mention the number of casualties. In other parts of her speech, she admitted that there were victims, but refused to admit they were victims of systematic mass killings. With this, Suu Kyi's strategy is related to Cohen's (2001) interpretative denial in terms of admitting there were victims, but denying the killings were genocidal.

\section{"There Were Victims on Both Sides, Thus It Cannot Be Called Systematic Killing”}

It has been argued that inclusive victim beliefs (i.e., claiming that everyone has suffered in similar ways in that context) can also be used strategically as a way for perpetrator groups to avoid responsibility (McNeill \& Vollhardt, 2020; Vollhardt, 2015). For instance, one of the strategies used to deny the Armenian genocide involved Turks' (the accused perpetrator group) claims that Turks were also victims of the war at the time, along with Armenians (Bilali, 2013; McNeill \& Vollhardt, 2020). In the case of the Rohingyas' suffering, Suu Kyi admitted that there were civilian victims because of the armed conflicts, but she emphasized that the victims were not just the Rohingya. She therefore claimed it could not be called genocide or ethnic cleansing because most residents were victims, regardless of religious or ethnic background.

Specifically, she argued that to understand what happened in Rakhine, people need to consider the historical situation, intergroup relations, and the occurrence of intergroup conflicts:

5) The file can be accessed through this link https://www.un.org/en/genocideprevention/documents/atrocity-crimes/Doc.1_Convention\%20on\%20the\%20Prevention $\% 20$ and $\% 20$ Punishment $\% 20$ of $\% 20$ the $\% 20$ Crime $\% 20$ of $\% 20$ Genocide.pdf

6) See the Supplementary Material for the full speech at the ICJ 


\section{Extract 3}

"[T]he troubles of Rakhine State and its population, whatever their background, go back into past centuries and have been particularly severe over the last few years [of internal armed conflict]."

She further argued that the government's social clashes were not just about Muslims. As seen in the following extracts, Suu Kyi explained that there were also Buddhists forming paramilitary groups attacking civilians as well as the Myanmar military. For example, she pointed to the Arakan Army (AA), which is one of the largest insurgent groups in Myanmar, and made up of mostly Buddhists:

\section{Extract 4}

Currently, an internal armed conflict is going on there - between the Arakan Army, an organised Buddhist armed group with more than 5,000 fighters, and the regular Myanmar Defence Services. [...] The Arakan Army seeks autonomy or independence for Rakhine [...] finding inspiration in the memory of the historic Kingdom of Arakan. This conflict has led to the displacement of thousands of civilians in Rakhine. Standard security restrictions - such as curfew and checkpoints - are in place at present in the conflict zone and affect the situation of civilians there, regardless of their background.

In the extract above, despite recognizing that the victims were civilians and military forces, Suu Kyi did not give estimated numbers of victims disaggregated according to religious category - namely, how many were Buddhists and how many were Muslims. ${ }^{7}$ Based on in-depth reports released by Human Rights Watch (2019) and BBC (2020), Muslim victims were indeed higher in numbers. By omitting such important details, Suu Kyi downplayed the victimization of Rohingya Muslims.

In the 2013 interview on BBC, the interviewer Mishal Husain explicitly asked Suu Kyi whether she would accept that the majority of victims have been Muslims. Suu Kyi responded that she admitted Muslims had been targeted, but it was also the case with Buddhists:

\section{Extract 5}

Yes Muslims have been targeted, but also Buddhists have been subjected to violence. But there is fear on both sides and this is what is leading to all this trouble. (Suu Kyi, 2013)

When the interviewer pointed out that in terms of the scale of the suffering, Muslims had been suffering most, and about hundreds of thousands of Muslims were displaced from their homes, Suu Kyi responded that many Buddhists had also been displaced from their country and were currently living in camps:

\section{Extract 6}

I think there are many, many Buddhists who have also left the country [...] and there are many Buddhists who are in refugee camps for various reasons. You will find them in Thailand, very many of them, and you will find them scattered all over the world. (Suu Kyi, 2013)

Here, instead of answering the question by agreeing or disagreeing, Suu Kyi used the argumentative strategy of selective inclusive victimhood to strengthen the ingroup's position in conflicts (Cohrs et al., 2015). Compared to competitive victimhood (Noor et al., 2012), selective inclusive victimhood served as a strategy Suu Kyi used to convince third parties that all religions were victims, thus avoiding Myanmar's perpetrator responsibility against Rohingya Muslims.

\section{"Many Parties Were Involved in the Conflict, Thus Every Group Is a Perpetrator"}

In addition to inclusive victimhood Suu Kyi's speech also implied inclusive perpetratorhood, emphasizing that many parties were involved in the conflict. In doing so, Suu Kyi explained that a perpetrator likewise becomes a victim. She

7) Exceptionally to the cases where Myanmar security forces were the victims (ex. See Supplementary Materials Line 44, 56, and 79). 
further emphasized that conflict within north Myanmar has thrived for years, since Muslims asked for an independent state, triggering a conflict between the Buddhists and Muslims:

\section{Extract 7}

It may aid the Court to briefly consider the historical significance of Maungdaw. When Britain made Burma a colonial entity separate from British India in 1937, the border between Burma and India was drawn along the river Naf, where we find today's border between Bangladesh and Myanmar.

Many Muslims gave their lives in combat against the Japanese in Rakhine. The sacrifices made by Muslim fighters motivated a call for the creation of an autonomous Muslim space in northern Rakhine, centred on Maungdaw. Whether or not this was encouraged by British officers, Britain rejected this call as soon as it had reoccupied Burma, before independence in 1948. The Muslim-Buddhist intercommunal violence of 1942 recurred in 1948 and several times after that. This cycle of violence has negatively affected life in northern Rakhine, making it the second poorest state in Myanmar.

Suu Kyi emphasized that Muslims were also the perpetrators. Moreover, other than trying to explain that intercommunal conflict occurred since Myanmar's independence, Suu Kyi argued that an external party, the British colonizers, contributed to present-day conflicts. This argument reflected outgroup blame, one form of moral disengagement (Bandura, 1999) through which Suu Kyi asserted that the government's infractions against the Rohingya Muslims were excusable and maintained the government's righteousness during the process of harmdoing.

According to Suu Kyi, the conflict became more complicated when Muslims in Rakhine formed an armed group named the Arakan Rohingya Salvation Army (ARSA) and launched multiple attacks in different locations.

\section{Extract 8}

The Arakan Rohingya Salvation Army - known as ARSA - launched simultaneous attacks [...] in northern Rakhine, near the border with Bangladesh. ARSA claimed responsibility for these attacks, which led to the death of nine police officers, more than 100 dead or missing civilians [...] This was the start of an internal armed conflict between ARSA and Myanmar's Defence Services which lasted until late 2017. The selective factual propositions contained in The Gambia's Application actually concern this conflict.

$[\ldots]$

There may have been several hundred casualties in some of the 12 locations. There was some inter-communal violence. Buddhist and Hindu minority communities also feared for their security after the original ARSA attacks and many fled from their homes.

From this quote, Suu Kyi emphasized that there were armed groups (i.e., perpetrators) from all sides, for example the Buddhists via AA (see Extract 4) and the Muslims via ARSA, therefore it was not clear who were the true victims. Going a step further, Suu Kyi pointed out an intragroup conflict within the Muslim community. In her 2017 BBC interview, she said that in Rakhine state, "it is Muslims killing Muslims as well". In doing this, Suu Kyi created the rhetoric that everybody was a perpetrator, as it was a case of internal conflict among Muslims.

Another instance where we can see how Suu Kyi denies ingroup wrongdoing is in how she responded to a question about the actions of security forces targeting the Rohingya. In the BBC interview in 2017, Fergal Keane asked whether security forces are free to rape, pillage, and torture when fighting breaks out. Suu Kyi responded that the army was "not free to rape, pillage and torture. That they're not free to do. They are free to go in and fight. That is in the constitution". In her response above, Suu Kyi's argument strengthened the jurisprudence of the army that de jure they are not free to commit torture and abuse, rather than arguing whether rape, pillage, and torture have, in fact, taken place. By doing so, Suu Kyi did not provide a firm yes or no answer nor did she provide facts about whether sexual abuses and violence occurred against the Rohingya. 
Nonetheless, Suu Kyi did not deny that security forces conducted the military operations in the contested area. Instead of using phrases like "military operations", "to battle" or "to attack", Suu Kyi used "to go in" and "fight", words considered to be more decent and acceptable. Such euphemistic language is commonly found to justify morally detrimental acts (Bandura, 1999).

\section{"There Were Misconducts by Law Enforcement but They Have Been Addressed"}

Suu Kyi also agreed that security forces committed wrongdoing against civilians. However, she claimed that the guilty were punished by law. According to her, the state has put on trial the law enforcement officers who had committed atrocious acts. Hence, Myanmar cannot be accused of systematically killing a specific group. Specifically, she stated:

\section{Extract 9}

It may be worth noting that the use of air power in military operations was avoided as far as possible to minimise the risk of collateral damage. However, in one incident, in order to be able to extract a unit surrounded by hundreds of ARSA fighters, the use of a helicopter was required. There was shooting from the helicopter which resulted in fatalities, which may have included noncombatants.

[...] There may also have been failures to prevent civilians from looting or destroying property after fighting or in abandoned villages. But these are determinations to be made in the due course of the criminal justice process, not by any individual in the Myanmar Government. [...] Surely, under the circumstances, genocidal intent cannot be the only hypothesis.

In the above statements, after acknowledging the mistakes of military personnel in harming civilians, Suu Kyi explained that the government tried its best to minimize the number of non-combatant victims. However, she also admitted that it was difficult to differentiate between rebels and "real" residents, thus she considered that civilians may have become unintended victims. She therefore asked the audience in the ICJ to understand the complexity of the situation.

Although she admitted that there were errors in the government's law enforcement, she also assured the audience that those who committed such errors would be brought to trial. Suu Kyi provided evidence for this:

\section{Extract 10}

As part of the overall efforts of the Myanmar Government to provide justice, a court-martial found that 10 Muslim men had been summarily executed in Inn Din village, one of the 12 locations of serious incidents [...] It sentenced four officers and three soldiers each to ten years in prison with hard labour. After serving a part of their sentences, they were given a military pardon. Many of us in Myanmar were unhappy with this pardon.

Other cases are undertaken without controversy. In the Mansi case, for example, a court-martial sat close to the location in Kachin State where three internally displaced civilians were killed. It sentenced six soldiers, each to 10 years in prison, in January 2018. Relatives of the victims and local civil society representatives were invited to the sentencing.

By presenting such evidence, she then asked the jurors in the ICJ whether it was correct to charge Myanmar of genocidal acts:

\section{Extract 11}

Can there be genocidal intent on the part of a state that actively investigates, prosecutes and punishes soldiers and officers who are accused of wrongdoing? Although the focus here is on members of the military, I can assure you that appropriate action will also be taken against civilian offenders, in line with due process. There will be no tolerance of human rights violations in the Rakhine, or elsewhere in Myanmar.

In the extract above, Suu Kyi pointed out that if there were misconducts among military officers, these could not be called genocide. It was also likely that Suu Kyi intended to show the audience a positive image of Myanmar 
(Augoustinos \& Every, 2007) by presenting evidence that the government was, in fact, abiding by humanitarian laws and would not hesitate to apply it indiscriminately, including to members of the ingroup - in this case, Myanmar security forces. Suu Kyi claimed that if such misconducts indeed existed, they were violations of human rights and "could be relevant under international humanitarian law or human rights conventions, but not under the 1948 Genocide Convention."

\section{Positive Image Construction}

Accompanying Suu Kyi's denial of the Rohingya genocide, she likewise constructed a positive image of herself and her government, particularly in showing Myanmar as a moral and righteous nation that is innocent. Her rhetorical strategies emphasized two themes, namely: "we know the rule and know the consequence of the violation" and "as a peace supporter and warrior".

\section{We Know the Rule and Know the Consequence of the Violation}

Considering her experience at the UN, as well as in a nonviolent movement struggling for human rights and democracy in Myanmar, Suu Kyi was expected to have extensive knowledge about UN conventions. She used this to her advantage, as can be gleaned from the opening sentences of her speech, when she provided detailed information about the cases of genocide considered by the UN in the past after the Genocide Convention. She then stated that she knew there were Rohingya people living in shelters because of the conflicts and she argued such facts cannot be categorized as genocide as it was complicated and "not easy to fathom" as described in Extract 2.

As Suu Kyi claimed to know what was right and wrong, and believed that her country did not do any wrongdoing, her position and knowledge was used as a strategic tool to support the denial of genocide. Specifically, she implied: "We know about the Genocide Convention, thus how can we do such horrible things?"

Supporting human rights and moral values was also an important element of maintaining a positive group image (Augoustinos \& Every, 2007; Reicher et al., 2008). Towards the end of Suu Kyi's speech, she noted that Myanmar (she used the word "we") adhered to principles of "non-violence, human rights, national reconciliation, and rule of law". She then closed her speech by stating: "We look to justice as a champion of the reconciliation and harmony that will assure the security and rights of all people." Even before her closing, she underscored her character as a supporter of human rights. Thus, Suu Kyi was consistent in defining the norms and values of Myanmar society as moral. By positioning the ingroup's values in this way, she argued that genocide was not compatible with who "we" are. It seemed she wanted to express the sentiment: "We know the rule and what is wrong or right, thus why are we accused?"

Such arguments describing the ingroup as peaceful or caring about the people are not unique-as evident in Pol Pot's example after the Cambodian Genocide described earlier (Maguire, 2005). Nonetheless, Suu Kyi's statement was not just a speculation like Pol Pot's, but was supported by evidence. By providing such arguments and evidence, Suu Kyi expressed her objection to the accusations that Myanmar's government was responsible for mass killing and did not know the rule of human rights. In this way, Suu Kyi denied the violation of human rights.

\section{As a Peace Supporter and Warrior}

Suu Kyi in her speech explained that Myanmar's government was not silent and had been trying to solve a "humanitarian" problem of horizontal conflicts between groups in vulnerable areas. As described in the analysis of denial strategies, Suu Kyi explained that the government had ordered law enforcement to help tackle the problems in conflict areas: "Myanmar's Defense Services responded [to] [...] armed incidents in more than 60 locations". As shown in Extract 9, she stated "that the use of air power in military operations was avoided as far as possible to minimise the risk of collateral damage." Indirectly, it was meant to convey that accusing Myanmar of indifference about the problems had no basis. Here, the arguments maintaining positive image questioned the accusation, as if saying: "We tried our best to mitigate conflict and harm, so why are we being blamed?"

Moreover, she mentioned that the Myanmar government had put to trial people suspected of rights violations, regardless of their background (see Extract 10). She emphasized this by conveying the following: "Under its 2008 Constitution, [...] criminal cases against soldiers or officers for possible war crimes committed in Rakhine must be 
investigated and prosecuted by that system." Thus, she denied the accusation that the Myanmar government supported systematic killing as stated in Extract 11. This rhetorical argument to maintain a positive group image is akin to saying: "We have charged the ones who violated human rights law, so how can we be accused of planning systematic violence?"

Through the two ways of maintaining a positive image, "we tried our best to mitigate the conflict" and "we have processed the ones who violated human rights law", Suu Kyi's speech portrayed the Myanmar government as both supporting human rights and as a champion for justice. According to Suu Kyi, the government was not a silent witness of human rights violations and was genuinely in their embodiment of justice. They were not killing people, but rather protecting people. Through these arguments, Suu Kyi countered the issue of Myanmar's incapacity to handle its internal problems.

\section{Discussion}

The present research examined Suu Kyi's primary rhetorical defense at the ICJ to defend Myanmar against accusations of genocide targeting the Rohingya people. Through critical narrative analysis, our findings showed that Suu Kyi claimed that the Myanmar government's widespread killings of the Rohingya was not genocidal because: (a) armed conflict caused the mass displacements; (b) there were victims on both sides; (c) many parties were involved in the conflict so every group is a perpetrator of violence; (d) misconducts by law enforcement have been addressed. By making such arguments, Suu Kyi rhetorically constructs her own meaning of genocide - as entailing mass displacements and killings outside the context of armed conflict, where only one group is victimized, and misconducts remain unpunished.

Our findings contribute to extant literature on how and why groups deny collective violence (Bandura, 1999; Cohen, 2001). We provide qualitative evidence of how language in a leader's political speech reveals the dynamic way denial arguments are rhetorically constructed to defend the ingroup's wrongdoing and prevent receiving moral sanctions. By analysing Suu Kyi's speech at the ICJ, we contribute to the theoretical understanding of how denial arguments operate in a naturalistic and highly consequential real-world context. In particular, even though Suu Kyi admitted some degree of misconduct by Myanmar's law enforcement, she also claimed that they had been put on trial and the civilian victims were considered collateral damage, which fits the idea of interpretative denial (Cohen, 2001). Suu Kyi further admitted that there were people moving from their homes to find a safer place. However, again, according to her the killings cannot be called 'genocide'. This framing of the situation attempts to minimize collective harmdoing, which is a moral disengagement strategy coined by Bandura (1999).

Likewise, our findings suggest that Suu Kyi attempted to avoid acknowledging the evidence that there were in fact systematic mass killings of the Rohingya. It is important to look at how Suu Kyi described the victims and perpetrators and how this categorization is relevant to which side should carry the blame for the violence that ensued. On the one hand, Suu Kyi claimed all parties - not just the Rohingya - were victims of harm doing, but on the other, Suu Kyi also admitted that many parties were involved as perpetrators. What was conveyed by Suu Kyi then was not just about inclusive victimhood (Cohrs et al., 2015; McNeill \& Vollhardt, 2020), but also inclusive perpetratorhood. With this, rather than diffusing the blame to a specific subject (Wodak, 1991), Suu Kyi chose to convey that this was everybody's responsibility. By doing so, she then did not need to find reasons to justify such killings (Bandura, 1999) or blame the victims (Putra et al., 2018).

It is also worth noting that Suu Kyi highlighted the fact that the conflict is complicated and that the situation in Myanmar is unique. She described the history of the conflict dating back to events before independence to explain its complex underpinnings. This indicates that Suu Kyi positioned herself as an insider who knows more of what happened in Rohingya and should therefore be trusted. In doing so, the accusers are considered outsiders and do not know enough about the local situation. Thus Suu Kyi, as the representative of Myanmar people, claimed that others are misunderstanding the situation because they lack the knowledge and understanding of the Rohingya situation, thereby undermining their accusations of genocide.

With regards to the issue about civilian victims, Suu Kyi explained that the Myanmar government avoided the use of air attacks to avoid harming civilians. She admitted that there might be victims who were civilians, however she considered them collateral damage. This use of sanitizing language (see Bandura, 1999) is commonly found among 
deniers of wrongdoing (Bilali, Iqbal, \& Freel, 2019; Parent, 2016) to explain that they had done the right thing despite civilian fatalities. These arguments support the idea that since security forces had already tried to minimize the harm to civilians, any such casualties were simply an unintended yet understandable consequence of the conflict (Roblyer, 2005).

What is interesting to note is that, in her speech, Suu Kyi did not provide any specific details about the victims of conflict, such as the number of victims that were Rohingya. This raises the question why did Suu Kyi appear so knowledgeable about how the conflict caused many victims regardless of their background, but was in fact less informative about the specific number of victims on both sides? It is possible that Suu Kyi wanted to lead the audience to pay attention to other aspects of the conflict, especially the framing that everyone, regardless of one's ethnoreligious background, was a victim of the conflict. Blurring the facts and alluding to other frames or narratives are not new occurrences in cases of denial of ingroup wrongdoing. For instance, in history books used for school students in Indonesia, there is typically no explanation of the 1965-66 massacres of people accused of affiliating with communism (Putra et al., 2019). Instead, textbooks highlight that communists were barbaric, evil, or cold-blooded killers. Similar narratives were also found in history books in Turkey denying the Armenian genocide (Bilali, 2013).

In tandem with defensive denial arguments, our research shows how constructing a positive ingroup image can serve to reiterate or enhance the persuasive power of denial. Previous studies (see Augoustinos \& Every, 2007; Chiang, 2010) have shown that presenting a positive group image is useful to convince people that the accused are not violating a moral standard. Highlighting groups norms of ethical and just behaviors mean that the group can avoid moral sanctions (Bandura, 1999; Putra, 2016). Extrapolating from our findings, people who know about humanitarian law and human rights issues may be more sophisticated and even effective in using their strategies of denying ingroup wrongdoing. Thus, for organisations like the ICJ, it is important to consider whether and how a nation's positive image and reputation should factor into decisions to intervene and/or punish offenders of mass atrocities.

It is interesting to compare the ICJ case surrounding the Rohingya genocide to the Indonesian mass killings of the 1965-66 where there was a tribunal held in the Netherlands in 2015 (i.e., the International People's Tribunal or IPT 1965). During this event, Indonesian authorities asked other countries not to intervene in Indonesia's internal problems, as such problems can be solved by themselves (Berita Satu, 2015). Instead of using confrontational arguments like what was used by Indonesian authorities, Suu Kyi showed evidence that the Myanmar government could solve their domestic problems. More often, confrontational arguments can backfire, and Suu Kyi might have predicted such an impact, therefore avoiding such claims in her speech. Rather, she used evidence to support her arguments that Myanmar's government did enforce justice indiscriminately in attempting to address the killings. Such a rhetorical strategy presented Myanmar as trustful and moral, a description far from features of genocide perpetrators.

\section{Limitations and Future Directions}

Finally, we consider the limitations of our study and suggestions for future research. First, despite Suu Kyi's presence at the ICJ as Myanmar's representative, she does not represent all voices and political factions of the Myanmar people (e.g., Muslims, political oppositions, other minority groups). More research is therefore needed to examine the narrative discourse of the Rohingya crisis among Myanmar's majority and minority groups. Further, as the present study focused on denial of mass violence through Suu Kyi's speeches at the ICJ in December 2019, it is important for future research to examine whether denial tactics changed since the ICJ ordered Myanmar to prevent genocidal acts against the Rohingya Muslims in January 2020. After all, the Rohingya crisis is one of the biggest humanitarian crises of our generation. The ways in which Myanmar officials discuss mass killings against the Rohingyas may have important implications for how this conflict will unfold in the future. In addition, while the present research sheds light on the denial strategies evident in Suu Kyi's speech, further work is needed to understand the extent to which these tactics were effective, and for whom. Perhaps these denial strategies were persuasive to the majority group in Myanmar who see Suu Kyi as their leader, but not to third parties or international observers of the conflict.

Further research is needed to understand the implications of the denial strategies identified in this research. In particular, we argue that inclusive perpetratorhood (together with inclusive victimhood), in which many parties are said to be involved in harm doing, may lead people to be less empathic toward those who suffered the most. This needs further empirical testing to examine whether the more people see others as part of a perpetrator group, the less 
empathetic they are towards the group's suffering as victims. In other words, applying the label of both victims and perpetrators to a particular group may reduce the extent to which third parties may want to intervene to help the group. It is also important to further examine whether the framing of victims as "fighting back" in self-defense may evoke the perpetrator label. Similar labeling arose in relation to Tamils who have mobilized to fight for an independent state against the Singhalese government of Sri Lanka, Palestinians who resisted Israelis' occupation of their land, and Armenians who resisted the genocide committed by the Ottoman Empire (Bilali, 2013), it is possible that collectively resisting and committing violence for self-defense may reduce bystanders' empathy when these victimized groups are constructed as perpetrators.

To conclude, the present study has shown the dynamic arguments of denial and the construction of a positive group image in response to accusations of ingroup harmdoing. Our analysis reveals the multiple ways in which Suu Kyi as a leader of Myanmar denied the accusation of the Rohingya genocide. For each of her denial arguments, Suu Kyi also attempted to show evidence of her claims. In doing so, she constructed a positive image of Myanmar and utilized her background as a human rights activist to help conjure this narrative.

Funding: The authors have no funding to report.

Acknowledgments: The authors have no support to report.

Competing Interests: Idhamsyah Eka Putra and Hema Preya Selvanathan are Associate Editors of JSPP but played no editorial role in this particular article or intervened in any form in the peer review process.

\section{Supplementary Materials}

The Supplementary Material is a transcription of Aung San Suu Kyi's full speech at the International Court of Justice in December 2019 (for access see Index of Supplementary Materials below).

\section{Index of Supplementary Materials}

Putra, I. E., Selvanathan, H. P., Mashuri, A., \& Montiel, C. J. (2021). Supplementary materials to "Aung San Suu Kyi's defensive denial of the Rohingya massacre: A rhetorical analysis of denial and positive-image construction" [Additional information]. PsychOpen

GOLD. https://doi.org/10.23668/psycharchives.5058

\section{References}

Aljazeera. (2019, December 11). Aung San Suu Kyi defends Myanmar against genocide allegations. Aljazeera.com. Retrieved from https://www.aljazeera.com/news/2019/12/myanmar-suu-kyi-stand-genocide-case-hague-191211054254397.html

Augoustinos, M., \& Every, D. (2007). The language of "race" and prejudice: A discourse of denial, reason, and liberal-practical politics. Journal of Language and Social Psychology, 26, 123-141. https://doi.org/10.1177/0261927X07300075

Bandura, A. (1999). Moral disengagement in the perpetration of inhumanities. Personality and Social Psychology Review, 3, $193-209$. https://doi.org/10.1207/s15327957pspr0303_3

BBC. (2020, January 23). Myanmar Rohingya: What you need to know about the crisis. bbc.com. Retrieved from https://www.bbc.com/news/world-asia-41566561

BBC. (2021, February 1). Myanmar coup: Aung San Suu Kyi detained as military seizes control. bbc.com. Retrieved from https://www.bbc.com/news/world-asia-55882489

Berita Satu. (2015, November 10). Gelar Pengadilan Rakyat Internasional, Wapres Sindir Belanda. Retrieved from https://www.beritasatu.com/dunia/321083/gelar-pengadilan-rakyat-internasional-wapres-sindir-belanda

Bilali, R. (2013). National narrative and social psychological influences in Turks' denial of the mass killings or Armenians as genocide. The Journal of Social Issues, 69, 16-33. https://doi.org/10.1111/josi.12001 
Bilali, R., Iqbal, Y., \& Freel, S. (2019). Understanding and counteracting genocide denial. In L. S. Newman (Ed.), Confronting humanity at its worst: Social psychological perspectives on genocide (pp. 288-315). New York, NY, USA: Oxford University Press.

Bilali, R., \& Vollhardt, J. R. (2019). Victim and perpetrator groups' divergent perspectives on collective violence: Implications for intergroup relations. Political Psychology, 40(S1), 75-108. https://doi.org/10.1111/pops.12570

Brown, R., Zagefka, H., González, R., Manzi, J., \& Čehajić, S. (2008). Nuestra culpa: Collective guilt and shame as predictors of reparation for historical wrongdoing. Fournal of Personality and Social Psychology, 94, 75-90. https://doi.org/10.1037/0022-3514.94.1.75

Chiang, S. Y. (2010). 'Well, I'm a lot of things, but I'm sure not a bigot': Positive self-presentation in confrontational discourse on racism. Discourse \& Society, 21, 273-294. https://doi.org/10.1177/0957926509360653

Cohen, S. (2001). States of denial: Knowing about atrocities and suffering. Cambridge, United Kingdom: Polity.

Cohrs, J. C., McNeill, A., \& Vollhardt, J. R. (2015). The two-sided role of inclusive victimhood for intergroup reconciliation: Evidence from Northern Ireland. Peace and Conflict, 21(4), 634-647. https://doi.org/10.1037/pac0000141

Edwards, D. (1991). Categories are for talking: On the cognitive and discursive bases of categorization. Theory \& Psychology, 1(4), 515-542. https://doi.org/10.1177/0959354391014007

Gibson, S. (2013). Milgram's obedience experiments: A rhetorical analysis. British fournal of Social Psychology, 52(2), $290-309$. https://doi.org/10.1111/j.2044-8309.2011.02070.x

Haque, M. M. (2017). Rohingya ethnic Muslim minority and the 1982 citizenship law in Burma. fournal of Muslim Minority Affairs, 37, 454-469. https://doi.org/10.1080/13602004.2017.1399600

Haslam, S. A., Reicher, S., \& Platow, M. J. (2011). The new psychology of leadership: Identity, influence and power. Hove, United Kingdom: Psychology Press.

Howitt, D. (2010). Introduction to qualitative methods in psychology. Harlow, United Kingdom: Prentice Hall.

Human Rights Watch. (2019). Myanmar: Crimes against Rohingya go unpunished. hrw.org. Retrieved from https://www.hrw.org/news/2019/08/22/myanmar-crimes-against-rohingya-go-unpunished

Kiernan, B. (2003). The demography of genocide in Southeast Asia: The death tolls in Cambodia, 1975-79, and East Timor, 1975-80. Critical Asian Studies, 35(4), 585-597. https://doi.org/10.1080/1467271032000147041

Leach, C. W., Zeineddine, B., \& Čehajić-Clancy, S. (2013). Moral immemorial: The rarity of self-criticism for previous generations' genocide or mass violence. The Journal of Social Issues, 69, 34-53. https://doi.org/10.1111/josi.12002

Le Couteur, A., \& Augoustinos, M. (2001). The language of prejudice and racism. In M. Augoustinos \& K. Reynolds (Eds.), Understanding prejudice, racism, and social conflict (pp. 215-230). London, United Kingdom: SAGE. Retrieved from http://digital.library.adelaide.edu.au/dspace/handle/2440/30528

Lee, R. (2014). A politician, not an icon: Aung San Suu Kyi’s silence on Myanmar's Muslim Rohingya. Islam \& Christian-Muslim Relations, 25, 321-333. https://doi.org/10.1080/09596410.2014.913850

Leidner, B. (2015). America and the age of genocide: Labeling a third-party conflict "genocide" decreases support for intervention among ingroup-glorifying Americans because they down-regulate guilt and perceived responsibility to intervene. Personality and Social Psychology Bulletin, 41, 1623-1645. https://doi.org/10.1177/0146167215607195

Leidner, B., Castano, E., Zaiser, E., \& Giner-Sorolla, R. (2010). Ingroup glorification, moral disengagement, and justice in the context of collective violence. Personality and Social Psychology Bulletin, 36(8), 1115-1129. https://doi.org/10.1177/0146167210376391

Madill, A., Jordan, A., \& Shirley, C. (2000). Objectivity and reliability in qualitative analysis: Realist, contextualist and radical constructionist epistemologies. British fournal of Psychology, 91(1), 1-20. https://doi.org/10.1348/000712600161646

Maguire, P. (2005). Facing death in Cambodia. New York, NY, USA: Columbia University Press.

McNeill, A., \& Vollhardt, J. (2020). “We all suffered!" - The role of power in rhetorical strategies of inclusive victimhood and its consequences for intergroup relations. In J. R. Vollhardt (Ed.), The social psychology of collective victimhood (pp. 337-358). New York, NY, USA: Oxford University Press.

Montiel, C. J., Umel, A., \& de Leon, M. (2016). Discursive construction of political categories and moral fields: God versus rights and access in a reproductive health legislative debate. Political Psychology, 37, 853-866. https://doi.org/10.1111/pops.12308

Morselli, D., \& Passini, S. (2010). Avoiding crimes of obedience: A comparative study of the autobiographies of M. K. Gandhi, Nelson Mandela, and Martin Luther King, Jr. Peace and Conflict, 16, 295-319. https://doi.org/10.1080/10781911003773530

Murray, M. (2003). Narrative psychology. In J. A. Smith (Ed.), Qualitative psychology: A practical guide to research methods (pp. 111131). London, United Kingdom: SAGE. 
Noor, M., Shnabel, N., Halabi, S., \& Nadler, A. (2012). When suffering begets suffering: The psychology of competitive victimhood between adversarial groups in violent conflicts. Personality and Social Psychology Review, 16, 351-374. https://doi.org/10.1177/1088868312440048

Parent, G. (2016). Genocide denial: Perpetuating victimization and the cycle of violence in Bosnia and Herzegovina (BiH). Genocide Studies and Prevention, 10, 38-58. https://doi.org/10.5038/1911-9933.10.2.1369

Parker, I. (2013). Discourse analysis: Dimensions of critique in psychology. Qualitative Research in Psychology, 10, $223-239$. https://doi.org/10.1080/14780887.2012.741509

Parnini, S. N. (2013). The crisis of the Rohingya as a Muslim minority in Myanmar and bilateral relations with Bangladesh. fournal of Muslim Minority Affairs, 33, 281-297. https://doi.org/10.1080/13602004.2013.826453

Peetz, J., Gunn, G. R., \& Wilson, A. E. (2010). Crimes of the past: Defensive temporal distancing in the face of past in-group wrongdoing. Personality and Social Psychology Bulletin, 36(5), 598-611. https://doi.org/10.1177/0146167210364850

Pletcher, K. (2019, December 26). Aung San Suu Kyi: Myanmar politician and opposition leader. brittanica.com. Retrieved from https://www.britannica.com/biography/Aung-San-Suu-Kyi.

Popham, P. (2012). Aung San Suu Kyi. Oxford, United Kingdom: St Hugh's College Oxford Magazine.

Putra, I. E. (2016). Representations and discourse about religion and Chinese descendants in 2012 Jakarta's election. Qualitative Report, 21, 1799-1816.

Putra, I. E., Holtz, P., \& Rufaedah, A. (2018). Who is to blame, the victims or the perpetrators? A study to understand a series of violence targeting accused heretic group. Psychology of Religion and Spirituality, 10, 166-173. https://doi.org/10.1037/rel0000186

Putra, I. E., Wagner, W., Rufaedah, A., \& Holtz, P. (2019). Identity, representations, religion and apologizing for past wrongdoings: Muslim discourse about Indonesia's 1965-66 massacres of communists. Journal of Community \& Applied Social Psychology, 29, 492-503. https://doi.org/10.1002/casp.2419

Rahman, U. (2010). The Rohingya refugee: A security dilemma for Bangladesh. Journal of Immigrant \& Refugee Studies, 8, $233-239$. https://doi.org/10.1080/15562941003792135

Reicher, S., Haslam, S. A., \& Hopkins, N. (2005). Social identity and the dynamics of leadership: Leaders and followers as collaborative agents in the transformation of social reality. The Leadership Quarterly, 16, 547-568. https://doi.org/10.1016/j.leaqua.2005.06.007

Reicher, S., Haslam, S. A., \& Rath, R. (2008). Making a virtue of evil: A five-step social identity model of the development of collective hate. Social and Personality Compass, 2, 1313-1344. https://doi.org/10.1111/j.1751-9004.2008.00113.x

Roblyer, D. A. (2005). Beyond precision: Morality, decision making, and collateral casualties. Peace and Conflict, 11, 17-39. https://doi.org/10.1207/s15327949pac1101_3

Shermer, M., \& Grobman, A. (2009). Denying history: Who says the Holocaust never happened and why do they say it. Berkeley, CA, USA: University of California Press.

Simon, B., \& Klandermans, B. (2001). Politicized collective identity: A social psychological analysis. The American Psychologist, 56(4), 319-331. https://doi.org/10.1037/0003-066X.56.4.319

Souto-Manning, M. (2014). Critical narrative analysis: The interplay of critical discourse and narrative analyses. International fournal of Qualitative Studies in Education, 27(2), 159-180. https://doi.org/10.1080/09518398.2012.737046

UNHRC. (2018). Myanmar: UN Fact-Finding Mission releases its full account of massive violations by military in Rakhine, Kachin and Shan States. Retrieved from https://www.ohchr.org/EN/HRBodies/HRC/Pages/NewsDetail.aspx?NewsID=23575

Van Dijk, T. (1993). Principles of critical discourse analysis. Discourse \& Society, 4, 249-283. https://doi.org/10.1177/0957926593004002006

Vollhardt, J. R. (2015). Inclusive victim consciousness in advocacy, social movements, and intergroup relations: Promises and pitfalls. Social Issues and Policy Review, 9, 89-120. https://doi.org/10.1111/sipr.12011

Vollhardt, J. R., Mazur, L. B., \& Lemahieu, M. (2014). Acknowledgment after mass violence: Effects on psychological well-being and intergroup relations. Group Processes \& Intergroup Relations, 17(3), 306-323. https://doi.org/10.1177/1368430213517270

Wodak, R. (1991). Turning the tables: Antisemitic discourse in post-war Austria. Discourse \& Society, 2, 65-83. https://doi.org/10.1177/0957926591002001004

Wodak, R. (2006). History in the making/The making of history: The 'German Wehrmacht' in collective and individual memories in Austria. Critical Linguistic Perspectives on Coping with Traumatic Pasts, 5(1), 125-154. https://doi.org/10.1075/jlp.5.1.08wod

Wodak, R., de Cillia, R., Reisigl, M., \& Liebhart, K. (2009). The discursive construction of national identity. Edinburgh, United Kingdom: Edinburgh University Press. 
Wohl, M. J. A., Branscombe, N. R., \& Klar, Y. (2006). Collective guilt: Emotional reactions when one's group has done wrong or been wronged. European Review of Social Psychology, 17, 1-37. https://doi.org/10.1080/10463280600574815

Xchange.org. (2019). The Rohingya survey 2019. Retrieved from http://xchange.org/reports/TheRohingyaSurvey2019.html 